DOI: $10.1515 / \mathrm{rpp}-2016-0043$

Doctor of Pedagogical Sciences, Senior Research Fellow, GALYNA SOTSKA Institute of Pedagogical Education and Adult Education of NAPS of Ukraine Address: 9 M. Berlynskogo St., Kyiv, 04060, Ukraine E-mail: galasotska@ukr.net

\title{
FORMING FUTURE TEACHERS' AESTHETIC CULTURE IN FOREIGN EDUCATIONAL PRACTICE
}

\begin{abstract}
The article deals with a theoretical analysis of foreign educational experience in solving scientific problems of forming future teachers' aesthetic culture. Given the current socio-cultural situation, it has been noted that a teacher who developed his/her aesthetic culture can make a direct contribution to the social and cultural challenges of a changing world. Based on the study of scientific and pedagogical literature, normative and legal support and the content of practical courses, the author has revealed the peculiarities of forming future specialists' aesthetic culture in foreign countries (Japan, Germany, Canada, the United States, England). Special attention has been paid to the aesthetic potential of fine arts in forming future teachers' aesthetic culture, which ensures the harmony of intellectual and aesthetic development of personality, enriches the emotional and sensual sphere, develops cognitive and creative activities, aesthetic needs and tastes, stipulates for future teachers' involving in the process of artistic and aesthetic culture of the nation. The performed analysis proves that the forming of future teachers' aesthetic culture should be based on the intercultural approach; the ideas of interrelation between aesthetic and ecological in aesthetic education; integration relations between powerful potential of fine (visual) arts, environmental science and aesthetic creativity. The experience of foreign educational practice may be adopted by domestic universities to form individual aesthetic culture of future teachers.

Key words: aesthetic culture, future teacher, ikebana art, calligraphy art, Waldorf pedagogy, multicultural approach, "environmental artists", integrative study of art.
\end{abstract}

\section{INTRODUCTION}

In terms of Ukrainian education integration in the European scientific, humanitarian and socio-cultural space quite topical are becoming the issues of forming a modern teacher's aesthetic culture. This integrated personal and professional formation is the basis for professional activity as a teacher with aesthetic culture formed is able to design his/her own professional activity in accordance with universal aesthetic values and humanistic worldview.

In the UNESCO report on a global strategy for education development in the 21 st century it is stated that culture and art are the most important components of a comprehensive education that ensures the full development of the human personality, namely, creative, cognitive, emotional, aesthetic, social and spiritual. From this standpoint, the search for strategies for forming aesthetic culture of future teachers is acquiring more and more importance abroad, including Japan, Germany, Canada, the United States and England. Therefore, rather valuable is the research on theoretical and practical experience in forming future teachers' aesthetic culture aimed at extrapolating positive achievements in foreign practice to Ukrainian educational space. 


\section{THE AIM OF THE STUDY}

The aim of the article is to study practical foreign experience in forming future teachers' aesthetic culture to apply it to the national teacher education.

\section{THEORETICAL FRAMEWORK AND RESEARCH METHODS}

The theoretical framework of the research is based on the works of scholars and educators from the United States, Japan, Canada, Germany, England where the ideas of forming future teachers' aesthetic culture are highlighted. In particular, K. Koikeu, I. Tamaki, R. Steiner reveal the aesthetic and pedagogical potential of fine arts based on the principle of "art prior intellectual" in forming future teachers' aesthetic culture. S. Robert and L. Louie justify the integrative interrelation of aesthetic and ecological in forming aesthetic culture of future specialists. Different aspects of forming future teachers' aesthetic culture are emphasized in the researches of many pedagogues (M. Billings, G. Blocke, H. Jiesamfoek, L. Mvanka, F. Robin, L. Stuhr et al.). Scholars maintain the position of a multicultural approach, whereby a modern teacher with aesthetic culture formed should be the bearer of universal and national culture in its intellectual and aesthetic manifestation that recognizes the cultural mission of education and his/her profession. The proposed consideration confirms the need for theoretical analysis of foreign experience in forming aesthetic culture of future teachers.

To achieve the aim of our research we have used the following methods: analysis, systematization and generalization of foreign and domestic scientific and pedagogical literature.

\section{RESULTS}

The study of scientific literature supports the conclusion that aesthetic culture is a fundamental spiritual need of the human personality, which occurs in the spiritual and practical transforming activities and is connected with the expansion of his/her ideological orientation, forming of world perception according to the laws of beauty.

The experience of foreign countries in forming aesthetic culture of the human personality in the context of teacher education proves that art, particularly, fine arts, has a strong potential in forming future teachers' aesthetic culture as it influences the inner world of the human personality, refers to human emotions, teaches to adapt to occurring changes, awakens receptivity to beauty, encourages the development of artistic and imaginative thinking, associative memory, imagination.

It should be mentioned that fine arts have been used to form aesthetic culture of the human personality since ancient times. Thus, the first mention of art as a discipline can be traced in works by Aristotle (381-322 BC), who created the doctrine of "mimesis", i.e. the reflection of reality and nature in the works of art. Aristotle considered grammar, gymnastics, music and painting to be primary subjects.

In Sicyon school founded by Pamphilus at the beginning of the 6th century BC and celebrated for its painters and sculptors, pupils studied painting, including pictorial art, based on geometry.

In ancient Rome, grammar and painting were considered to be main disciplines. According to Plato, they were a prerequisite for the study of more complex subjects where painting was the primary means of forming sophistication, achieving physical perfection, creating aesthetic perfection of the subject environment.

It was ancient thinkers who formulated approaches to comprehend aesthetic and educational potential of fine arts that later became the methodological basis of the problem of forming future teachers' aesthetic culture in modern foreign educational practice. 
Of particular interest is Japanese experience in using fine arts to form the aesthetic culture of future teachers based on the ideas of $\mathrm{M}$. Tsunesaburo set out in his work "The System of Pedagogy Aimed to Create Values", where the author develops the concept of "cultural education". It lies in the fact that the ultimate purpose of man and his pleasure is to create fundamental values - benefit, beauty, kindness (Nakamura, 1967). In order to enable students to gain knowledge and practical experience in traditional arts, with further preservation and transmission of traditions to future generations within the State Concept of Education of Japan (White Paper) the program "Implementation of Traditional Art Classes" was launched in 2003

One of the traditional kinds of fine arts in Japan is calligraphy, which contributes to accuracy of paintings, confidence of strokes, sophistication of lines, proportion of volumes. Mastering the art of calligraphy future teachers comprehend the principles of artistic generalization and symbolization. Through rhythm, structure and harmony a hieroglyph conveys plasticity of movement in imaginary correlation of an object with its hieroglyphic generalized concrete image, namely, an object of aesthetic perception. "If one refers to the works of Japanese writing", says a master and theorist of calligraphy A. Capra, "then even without understanding the meaning of these writings one can experience high aesthetic feelings" (Daniels, Bright, 1996).

The subtleties of the thinking process, reflected in brevity, plasticity and elegance of lines, help to understand and realize the requirements of the principle of building an artistic form and developing aesthetic imagination. Beauty in all its forms and manifestations serves as an object of aesthetic perception. Encouraging to feel and understand beauty during fine art classes stipulates for the development of future teachers' aesthetic feelings and emotions that contribute to the forming of the human soul, "Theoretical constructions are impossible if they are not based on sharp and strong feelings - it would be like sand castles" (Мотому, 1977).

An important role in forming future teachers' aesthetic culture belongs to the study of colour as the main means of artistic expression and students' personal development. Teaching colour studies solves the problem of future teachers" "colour disease" (i.e. the absence of any color spectrum), which leads to mastering the knowledge of colour systems as the basis of their personal spiritual harmony.

Future teachers' comprehending colour enables them to perceive the world through colour, understand its beauty and the joy of creativity together with colour combinations, foster cultural artistic and aesthetic perception of colour in nature, life, art and to form a harmonious artistic and aesthetic vision: "harmony of colour - harmony of the soul - harmony in life".

The foundations of fine arts are laid in the art of ikebana (from Japanese 華道 "live flowers" or "the way of flowers"), which takes into consideration the laws of composition and colouring (integrity, harmony, rhythm, proportion, contrast, emphasis, nuance, etc.). Art teaches students how to identify the beauty of flowers and, therefore, the beauty of their own souls. This is a search for ideal beauty (Ikenobo Sen'ey, the 45th chairman of the Ikenobo school). I. Tamaki and K. Koike point out that ikebana is "a flower work" perceived through complex associations connected with aestheticized change of seasons. Multidimensionality of composition stimulates unforgettable aesthetic feelings (Tamaka, Koike, 2004) that help to enhance the spirituality. Thus, one can observe the unity of worldview, expressive language and understanding of the creative act, a direct 
merge with the world that allows to reveal a hidden "charm of things" (mono no aware), to express individuality, unity and uniqueness of every phenomenon of reality (Киященко, 1998).

Waldorf pedagogy founded by an Austrian scholar and philosopher R. Steiner has a strong potential as it is based on his esoteric and philosophic concept - anthroposophy (the study of extrasensory perception of the world as a gradual self-improvement). It is recognized as a modern spiritual and scientific ecology of personality development, being a system of self-knowledge and self-development of each individual through the art means in the context of freedom to learn, education and creativity, in duality of empirical and extrasensory experience, spirit, soul and body. The fundamental principle of Waldorf education is based on the idea of "art prior intellectual".

Particularly valuable is the fact that fine arts (painting, sculpture, drawing) are taught during all the years of study (from the $1^{\text {st }}$ to $12^{\text {th }}$ grade) based on the integrative relations while studying all other subjects. It ensures profound aestheticization of the educational process and is characterized by an emotional and imaginative dominant rather than a traditional rational, logical and verbal one. Fine arts classes that are represented by such subjects Drawing, Painting, Drawing Shapes, Modeling, ensure sensory, artistic and practical cognition of reality and contribute to the development of artistic and aesthetic taste, aesthetic worldview.

Accordingly, future pedagogues' professional training for teaching mentioned subjects is focused on the "plotless drawing", "free artistic and plastic self-expression" that promotes creativity, artistic abilities, personal development through students' simple feelings and emotional responses to figurative aesthetic attitude.

R. Steiner believes that painting is an important key to emotional understanding of art through the language of colour of an objectively existing colourful world and emotional colour-based perception and feelings. Considering colour in the trinity of "painting feeling - color" Waldorf pedagogues associate it with the development of 12 senses (according to R. Steiner), that can be divided into three groups of four each as the ratio of the threefold division of man's connection with the world - with thinking, feeling and will, which leads to the development of artistic abilities. Senses of touch, life, movement and balance constitute the first group and are called bodily senses. The second group of senses (vision, warmth, smell) belongs to the human soul, her feelings and perceptions of the world. These are spiritual senses as their perception is always comparable in polar manifestations: sight - either beauty or ugliness; smell - good or bad; taste - sweet or bitter. The third group consists of such senses as hearing, speech or a sense of the word, imagination or a sense of the thought, "self", that stipulate for an internal "vision", enable to "talk" and "listen to" art and enjoy it. The development of colour and the formation of all these senses enrich personality, provide peace of mind, "opens the gate to the world" (Брюн, Лихтхар, 2011).

Drawing Forms ("as a branch of an art tree") introduced by R. Steiner is grounded on a new interpretation of certain components of form drawing and their interaction on the integrative basis (graphic activity as a motor artistic and imaginative activity), that means graphic images are accompanied by sketches of a plastic improvisation of form images.

The process of drawing different forms (round, oval, pyramidal) is directed at awakening the sense of form, emotional attitude towards it, developing students' artistic and creative thinking, perception and awareness of forms and proportions for both external features and its deep philosophical and aesthetic essence rather than their acquiring graphic skills. 
So, visual arts classes contribute to the development of future teachers' aesthetic senses, cognitive interests, aesthetic taste, sense of rhythm, form and harmony. As a result, one lays the foundation for the development of interest in life that is emotional and enriched with vivid experience being the basis for the forming of their aesthetic culture.

Interesting and topical for teacher education and practice are the views of R. Skraton, a professor of aesthetics in Birbeck, University of London. The scholar's leading idea justifies the interrelation between aesthetic and ecological components in forming aesthetic culture of specialists. In addition, aesthetics reveals the feasibility of human life through the categories of beauty and harmony, "Perceiving beauty man feels the laws of the creation of the world" (Scrutton, 1989). Comprehending the feasibility of the world and one's place in it, understanding the beauty of unity of form and content of the environment based on aesthetic experience allows to carry out and evaluate one's own activity from a position of absolute beauty, spirituality and morality.

Of important scientific interest is practical experience of L. Louis, a teacher of in New York college, who developed the course "Human Tracks in the Urban Landscape" to study the forming of aesthetic and ecological thinking, future teachers' acquiring aesthetic experience in interaction with nature, emotional and aesthetic reflections through artistic and aesthetic knowledge of the world (Linda, 2000).

The presented course is aimed at studying pedagogical principles of art based on the integrative relations of a strong potential of fine (visual) art, ecology, aesthetics and creativity. The main objective of the course is to encourage future teachers to create an ecoart project "Human Tracks" as an "open work" - an aesthetic message of the interaction between human and nature in the artistic and aesthetic form.

The teaching of the course is based on the use of art to study design and ecology, recognition of a place or an object of the environment as a subject of research, learning and creativity; as a source of metaphor, inspiration, aesthetic feelings, aesthetic experience.

Mastering the course future teachers are becoming "environmental artists" that involves their collecting facts related to the area, representation of photo visual elements of natural and artificial (for example, lines and line types, light and shades, sizes, colour, texture, rhythmic repetition, forms, etc.) tracing identical visual elements in the world created by human and nature (a branch of a tree - a crack in asphalt, a pavement, honeycombs, etc.). The collected material is discussed in groups so that the issues of artistic, aesthetic, historical trends may be emphasized.

Based on the collected photographic material educators create an artistic and aesthetic "history", developing various compositions. Teachers pay attention to a strong potential of expressive means and techniques of fine arts (pictorial, graphic, collage making, etc.) with a combination of digital formats and written texts to create and present a project based on one's own research and aesthetic experience.

Moreover, pedagogues create sculptures or installations using objects made from natural materials or waste products of human activity (paper, cardboard, lids). It stipulates for the development of intuition, the ability to make aesthetic and environmental discoveries, contact with various materials (from visual to body and kinesthetic) as a manifestation of an aesthetic attitude to nature.

Such an approach is extremely effective as it encourages teachers towards a creative expression of anxiety about the ecological environment, the search for a new way to coexist with nature to restore the damaged environment through an artistic and aesthetic form, the realization of harmonious coexistence with nature. 
Rather relevant are the views of scholars from Canada, the USA, who emphasize the importance of taking into account a multicultural approach in training future teachers as the basis for the forming of their professional and aesthetic culture.

According to L. Stuhr, L. Mvanka, F. Wasson, this approach is aimed at future teachers' comprehending a cultural diversity in the world, studying the experience of aesthetic traditions, ethical changes and perceiving different cultural (aesthetic, artistic, ethnic) traditions. The scholars state that future teachers' studying and compiling experience of their and other cultures promotes their personal self-realization, expression of individuality and critical thinking development.

Thereby, main attention is paid to the importance of forming future teachers' ability to analyze a wide range of historical and contemporary aspects of culture in the context of artistic development as art, on the one hand, is always based on the formed aesthetic ideas, canons and ideals prevailing in culture of this society and, on the other hand, these ideas and ideals are turned into a unique work of art.

The basis for the views of M. Billings is an idea of comprehending different cultural traditions through the disclosure of aesthetic philosophy of artists - a way to a better understanding of their own culture, including aesthetic. Billings, 1995. This idea is developed by D. Blocker, a professor of aesthetics and philosophy of art at University of Ohio, who emphasizes the relation between art and students' life experience, that allows to reject formal focus only on the subject of art, express one's own position through visual form, reflecting the personal aesthetic experience, under-standing a particular problem in the context of his life and society (Blocke, 2004).

Stressing the fact that culture is very diverse, not only on the ethnical level, but also in determining life styles, artistic, aesthetic preferences and cultural trends, scholars believe that education should be multicultural, that means "any culture must not be dominative". According to D. Blocker, education should not limit students on account of their cultural roots, should form their personality via different cultures, that leads to "a better understanding of not only Western aesthetic standards, but also the breadth and diversity of Western aesthetics" (Blocke, 2004). This includes the realization of ideas of openness and multiperspective complementarity and mutual enrichment of different cultures, the dialogue of cultures in equal coexistence of national and global, the acquisition of experience of aesthetic traditions and cultivation of human values.

Quite original are the views of H. Jiesamfoek on the training of artists based on the development of their professionalism, general, artistic and aesthetic culture. The scholar emphasizes the importance of integrative study of art in the historical and contemporary context as the basis of art education for the forming of future art teachers' personal culture.

This can be achieved by the learning course "Important Historical and Contemporary Issues in Art Education: Social Values and Individual (Personal) needs" and its main themes are: "The Study of Educational Concepts and Art", "Art Education from the Classical Era to the Renaissance", "Art Education and the Era of Education", "Art, Aesthetics and Design", "Exchange of Views in Art", "The Impact on Art Education in the 20th Century", etc. H. Jiesamfoek appeals to the historical and contemporary art education ideas of art and human culture that promote students' awareness of their role as professionals with formed aesthetic culture in the creation of art educational environment which is multidimensional, multicultural, dialogic (Jiesamfoek, 1999).

\section{CONCLUSIONS}

In conclusion we would like to note that the ideas of foreign experience are topical and need to be adapted and implemented in the system of future teachers' training aimed at 
forming their aesthetic culture. Transforming the achievements of foreign scholars and educators the forming of the defined culture should be carried out on the basis of the intercultural approach; the ideas of the interrelation between aesthetic and ecological in the process of aesthetic education; the integrative relations of a strong potential of fine (visual) arts, environmental science and aesthetic creativity.

The perspectives for further investigations include the study of pedagogical conditions of forming specialists' aesthetic culture in foreign education systems.

\section{REFERENCES}

1. Billings, M.-M. (1995). Two Approaches to a Multicultural Art Curriculum. Art Education, Volume 48, No 1, pp. 21-56.

2. Blocke, G. H. (2004). Varieties of Multicultural Art Education: Some Policy Issues. Handbook of Research and Policy in Art Education, pp. 187-199.

3. Daniels, P., Bright, W. (1996). The World's Writing Systems. New York: Oxford : Oxford University Press, 920 p.

4. Jiesamfoek, H. (1999). Critical Historical and Current Issues in Art Education: Social Values and Individual Needs. NYork, $146 \mathrm{p}$.

5. Linda, L. (2000). Human Tracks in the Urban Landscape. NYork, 146 p.

6. Nakamura, H. (1967). A History of Development of Japanese Thought from 952 to 1868 . Tokyo, $475 \mathrm{p}$.

7. Scrutton, R. (1989). Modern Philosophy and the Neglect of Aesthetics. In : Abbs, P. (Ed.). The Symbolic Order: a Contemporary Reader on the Arts Debate, pp. 22-34.

8. Stuhr, L., Petrovich-Mwaniki, L., Wasson, F. (1992). Curriculum Guidelines for the Multicultural Art Classroom. Art Education, No 45 (1), pp. 16-24.

9. Tamaka, I., Koike, K. (2004). Japanese Coloring. Tokio : Minato-ku, 144 p.

10. Брюн, Д., Лихтхар, А. (2011). Живопись в образовании. Опыт вальдорфской школье [Art in Education. Waldorf School Experience]. К. : НАИР, 192 p. (in Russian).

11. Киященко, Н. И. (1998). Современные кониепты эстетического воспитания: теория и практика [Modern Concepts of Aesthetic Education: Theory and Prac-tice]. М. : Ифра, 313 p. (in Russian).

12. Мотому, Т. (1977). Нинген-но света-е-але тецугаку [Ningen-No Sveta-E-Ale Tetsugaku]. Философия человеческого будущегго [Philosophy of Human Future], 82 p. 